\title{
Evaluation of tear film stability in pterygium \& pingueculae
}

\author{
Amer Y. Rajab \\ From the Department of Surgery, College of Medicine, University of Mosul, Mosul, Iraq. \\ Correspondence: Amer Y. Rajab. ameryahya50@yahoo.com.
}

(Ann Coll Med Mosul 2013; 39 (2): 132-135).

Received: $7^{\text {th }}$ Mar. 2011; Accepted: $20^{\text {th }}$ Mar. 2013.

\section{ABSTRACT}

Objective: To assess the degree of tear film stability in eyes with pingueculae and ptergia in patients from Mosul.

Patients and methods: Case-control study from private clinic and Al-Jamhori Teaching Hospital during a period of one year from Feb. 2009.Tear break-up time were measured in 36 eyes with pterygia, and 37 eyes with pingueculae, compared to control group of 37 eyes.

Results: The mean tear break-up time (TBUT) was $11.1 \pm 3.6 \mathrm{sec}$. in the eyes with pingueculae \& $11.4 \pm 6$ sec. in the eyes with pterygium compared to $15 \pm 4.5 \mathrm{sec}$ in the control group. Unstable tear film (TBUT less than 10 secs.) was found in $17(47.2 \%)$ eyes with pterygia, compared to $13(35.1 \%)$ eyes with pingueculue and $7(18.9 \%)$ control eyes. Unstable tear film was significantly associated with eyes with pterygia.

Conclusion: Unstable tear film is associated more with pterygia than with pingueculae, other factors as environmental and racial ones should be evaluated.

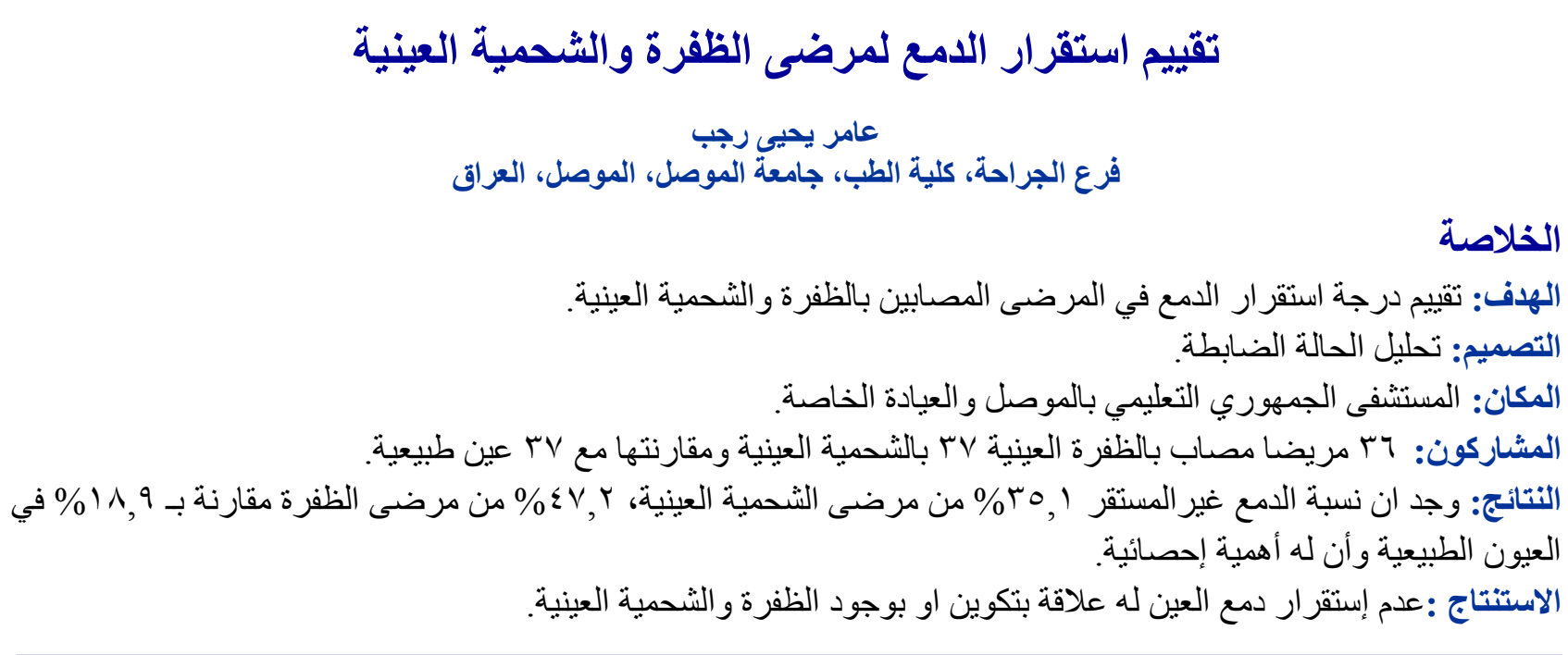

\section{INTRODUCTION}

$\mathrm{P}$ terygium is a fibro- vascular overgrowth of degenerative bulbar conjunctival tissue growing over the limbus onto cornea. ${ }^{1}$ It is worldwide disease that causes chronic irritation, impaired cosmoses, and decreased vision, secondary to the growth over the pupillary axis or induced astigmatism or disruption of the precorneal tear film. ${ }^{2}$

Pterygium is found in areas of bright sunlight and may be linked to ultraviolet (UV) light. ${ }^{3,4}$ It is thought that UV light causes destruction of the tear film due to rapid evaporation. ${ }^{5-7}$

A pingueculae is a round, yellowish, elevated tissue growth typically located at the limbus in the interpalpebral fissure ( 3 o' clock or 9 o'clock position). It is usually bilateral, more often at the nasal rather than temporal limbus. ${ }^{8}$

Precorneal tear film is formed of three layers; outer lipid layer, secreted by the meibomian glands and it's function is to prevent rapid evaporation of tears and lubricates the eyelids over the globe, middle aqueous layer, secreted by the lacrimal gland and it's function is to supply oxygen to the 
corneal epithelium and antibacterial as it contains lysozymes, inner mucinous layer, secreted by the goblet cells and functions to make the corneal epithelium hydrophilic. ${ }^{9}$

Tear film dysfunction has been found in subjects with pterygium and other degenerative lesions of the bulbar conjunctiva. ${ }^{8,10}$ Like pingueculae, in India investigators have found abnormalities of tear function, ${ }^{11,12}$ in eyes with pterygia and pingueculae, while others have found no such abnormalities. The exact etiologies of these benign peri -bulbar lesions are not known.

The tear break up time (TBUT) is crude measure of tear film stability, it is $15-30$ seconds in normal eye. $^{13}$

Many studies have been performed to investigate the correlation between the occurrence of pterygium and pingueculae, and dryness of the eyes. ${ }^{14-21}$

This study aims to assess tear film function in eyes with pterygia and pingueculae and a control group to determine the presence or absence of tear dysfunction

\section{PATIENTS AND METHOD}

All subjects (110), 20 years and older with primary pterygium and pingueculae, were recruited into the study from Al-Jamhori outpatient and a private clinic in one year period from February 2009.

The inclusion criteria were patients with pterygia, or with pingueculae. The patients in the control group were matched to the patients in the case study group, by age and gender. The control group did not have pterygia or pingueculae and had not used topical or systemic medications three months prior to the study. The control group was selected among subjects who presented with refractive errors and presbyopia

The exclusion criteria included any subject with other degenerative eye condition, dry eye syndrome, kerato-conjunctivitis sicca, blephroconjuctivitis and trachoma. Also exclusion list included subjects who had received topical eye medications or systemic medications such as antihistamines, phenothiazine, diazepam and artane and such drugs that may affect tear film stability in three months prior to the study. Information was obtained by personal interview.

Evaluation of the subjects, included, visual acuity testing, anterior segment examination with slit- lamp bio-microscope to ensure strict compliance with the inclusion and exclusion criteria.

Tear break-up time (TBUT) was measured by the author. It was determined by positioning the patient for slit-lamp examination while a fluorescein strip slightly moistened with sterile water was applied to the unanaesthetized inferior temporal bulbar conjunctiva of the eye. After three blinks the patient was asked to look straight ahead without blinking and without holding the lids, using cobaltblue filter from the slit-lamp and broad beam of light the corneal surface was scanned for the appearance of dark spot, or streak, on the cornea. The time from the last blink to the appearance of these spots was measured in seconds to determine the TBUT.

Three readings were taken and an average value was determined. Values within 10-45 seconds were taken as normal, less than $10 \mathrm{sec}$ was considered as unstable tear film, as previously categorized by Lemp. ${ }^{9}$

We conducted TBUT in order to evaluate the tear film function in eyes with pingueculae and pterygium. The results were considered abnormal or unstable, if TBUT was less than 10 seconds. ${ }^{20,23}$ It is known that the two eyes usually secrete tear equally, ${ }^{24}$ and therefore we evaluated tear function in random eyes of patients with pingueculae, pterygium and control groups.

\section{Stastistical analysis}

Stastical analysis was carried out by using $z$ test. The result was considered significant, if it was less than 0.05 .

\section{RESULTS}

A total of 110 subjects were studied, comprising of 36 subjects with pterygium, 37 subjects with pingueculae and a control group of 37 subjects. The age and sex distribution of the subjects are shown in Table 1.

The results of the TBUT in pingueculae, pterygium and control group are shown in Table 2. While in control group the mean TBUT was $15 \mp$ $4.5,7(18.9 \%)$ of eyes had unstable tear film in control group. P-value is highly significant (h.s) in pterygium and it is 0.01 , using $Z$ - test two proportions. 
Table 1. Age and sex distribution of subjects studied.

\begin{tabular}{|c|c|c|c|c|c|c|c|c|}
\hline \multirow[b]{2}{*}{ Age Group (Yrs) } & \multicolumn{2}{|c|}{ Control } & \multicolumn{2}{|c|}{ Pingueculae } & \multicolumn{2}{|c|}{ Pterygium } & \multicolumn{2}{|c|}{ Total } \\
\hline & No. & $\%$ & No. & $\%$ & No. & $\%$ & No. & $\%$ \\
\hline $20-29$ & 7 & 18.9 & 7 & 18.9 & 6 & 16.7 & 20 & 18.2 \\
\hline $30-39$ & 8 & 21.7 & 8 & 21.7 & 9 & 25 & 25 & 22.7 \\
\hline $40-49$ & 8 & 21.6 & 9 & 24.3 & 8 & 22.2 & 25 & 22.7 \\
\hline $50-59$ & 7 & 18.9 & 6 & 16.2 & 7 & 19.4 & 20 & 18.2 \\
\hline 60 and older & 7 & 18.9 & 7 & 18.9 & 6 & 16.7 & 20 & 18.2 \\
\hline \multirow[t]{2}{*}{ Total } & 37 & 100 & 37 & 100 & 36 & 100 & 110 & 100 \\
\hline & \multicolumn{2}{|c|}{ Control } & \multicolumn{2}{|c|}{ Pingueculae } & \multicolumn{2}{|c|}{ Pterygium } & \multicolumn{2}{|c|}{ Total } \\
\hline Sex & No. & $\%$ & No. & $\%$ & No. & $\%$ & No. & $\%$ \\
\hline Male & 19 & 51.3 & 20 & 54.1 & 18 & 50 & 57 & 51.8 \\
\hline Female & 18 & 48.7 & 17 & 45.9 & 18 & 50 & 53 & 48.2 \\
\hline Total & 37 & 100 & 37 & 100 & 36 & 100 & 110 & 100 \\
\hline
\end{tabular}

Table 2. Tear break up times in eyes with pingueculae, pterygium and control eyes (mean \pm standard deviation).

\begin{tabular}{lcccc}
\multicolumn{1}{c}{ Subjects group } & No. of eyes & TBUT $(\mathrm{sec})$ & Unstable TBUT & P. value \\
\hline Pingueculae & 37 & $11.1 \mp 3.9$ & $13(35.1 \%)$ & n.s \\
Pterygium & 36 & $11.4 \mp 6$ & $17(47.2 \%)$ & $0.01^{*}$ \\
Control & 37 & $15 \mp 4.5$ & $7(18.9 \%)$ & n.s. \\
\hline
\end{tabular}

Unstable TBUT= below $10 \mathrm{sec}$.

*significant.

\section{DISCUSSION}

Environmental factors, i.e. dry and dusty weather conditions and long periods of UV light exposure are being suggested as the major predisposing factors for the high incidence of pterygia and pingueculae. One theory suggests that chronic irritation from wind and dust causes corneal and conjunctival drying which predisposes the eye to pterygium. ${ }^{3-5}$ Others feel that UV light induces tear dysfunction, or that pterygium itself causes tear dysfunction. ${ }^{24}$ If factors other than environmental conditions play a role in the aetiology of pterygium, then tear studies in pterygium may not yield different results in different geographic locations.

In the present study however I did not attempt to diagnose the presence of dry eye per se, but was searching for occurrence of abnormal tear function test related to specific abnormality of ocular surface, as TBUT was less significant in the eye with pingueculae and pterygium than in the control group.

A rapid thinning of pre-corneal tear film as water evaporated from it, and alteration in surface tension, cause the break up phenomenon. Also the development of dry spots occurring in the same location may indicate a local corneal surface abnormality (e.g. epithelial basement membrane disease) rather than an intrinsic instability of tear film. ${ }^{22}$

The composition of tear film, including the lipid, aqueous and mucus layers and hydrodynamic factors, are extremely critical in tear film stability. ${ }^{25}$ The reduced TBUT can be caused by several mechanisms in such eyes; normal eyelid blinking may be compromised in the eyes with pingueculae and pterygium, that may lead to desiccated epithelium, and may result in less water stability and shorter TBUT, furthermore, the presence of irregularity in the surface epithelium, as in the case of pingueculae and pterygium, can compromise the surface tension and stability of tears.

The differences in TBUT could not be related to age or gender as shown by the study. Other causes of differences in TBUT such as trachoma or vitamin $\mathrm{A}$ deficiency ${ }^{24}$ were excluded in the studied subjects.

Hot climate had no effect, as it was found that TBUT had no correlation with humidity and temperature. ${ }^{25}$ If the environment is a causative factor in pterygium, it may be the effect of UV light rather than temperature and humidity.

Performance of the test can unlikely influence the results because the test is conducted by same person. Lemp ${ }^{9}$ and coworkers found that a TBUT 
of less than 10 secs. occurs in mucin-deficient dry eyes. This finding has been supported by conjunctival biopsies, while TBUT is variable in aqueous-deficient dry eyes ${ }^{26}$.

The marked abnormality of TBUT, which was found more frequently in association in eyes with pterygia than eyes without pterygia, also suggests that either there may be an abnormality of mucin, ${ }^{10,11}$ which may be a predisposing factor for the pathogenesis of pterygium (UV light may initiate the abnormality), or that pterygium itself casing abnormalities of mucin.

Whether tear dysfunction is the precursor or the result of pterygium is still not clear. Research and clinical evidence, however, suggest a relationship between the two.

A longitudinal study may provide more information on the sequence of events between tear film dysfunction and pterygium formation. Tear abnormalities were associated with pterygium and less so with pingueculae in the subjects studied.

\section{CONCLUSION}

Tear abnormalities were associated with pterygium and less so with pingueculae in the subjects studied.

\section{REFERENCES}

1. Mutlu FM, Sobaci G, Tator T, Yildirim E. A comparative study of recurrent pterygium surgery. Ophthalmology 1999; 106: 817-821.

2. Chen PP, Ariyasu RG, Kaza V. A randomized trial comparing mitomycin $\mathrm{C}$ and conjunctivalautograft after excision of primary pterygium. Am $\mathrm{J}$ ophthalmology. 1995;120:151-160.

3. Wong WW. Hypothesis on pathogenesis of pterygium. Ann. Of Ophthalmol 1978; 10: 303-8.

4. Detels R, DHIR SP. Pterygium: A geographical study. Arch ophthalmol 1967; 78: 485-91.

5. Archila EA, Arenas MC. Etiopathology of pinguecula and pterygium. Cornea 1995;14: 543-44.

6. Norn MS. Prevalence of pinguecula in Greenland and in Copenhagen, and its relation to pterygium and spheroid degeneration. Acta Ophthalmol 1979; 57: 96105.

7. Hill JC, Maske R. Pathogenesis of pterygium. Eye 1989; 3:218-26.

8. Karmer SG. Pingueculae and pterygia. Survophthalmol 1988;32:41-49.
9. Lemp MA, Holly FJ, Iwata S, Dohlman $\mathrm{CH}$. The precorneal tear film $\mathrm{I}$ : factors in spreading and maintaining continuous tear film over the corneal surface. Arch Ophthal 1970; 83:89-94.

10. Oguz H, Karadede S, Bitiren M, Gurler B, Cakmak M. Tear functions in patients with pinguecula. Acta Ophthalmol Scand. 2001 June; 79: 262-5.

11. Kadayifcilar SC, Orhan M, Irkec M. Tear function in patients with pterygium. Acta Ophthalmol Scand 2004; 76:176-179.

12. Rajiv MS, Sood AK. Pterygium and dry eyes. A clinical correlation. Indian J. of Ophthalmol 1991; 39: 1516.

13. Ferris J. Basic science in ophthalmology. A self assessment text ocular physiology. $2^{\text {nd }}$ ed. BMJ Publishing Group;1999. p. 291.

14. Bekibele CO, Baiyeroju AM, Ajaiyeoba A, et al. Case control study of dry eye and related ocular surface abnormalities in Ibadan, Nigeria. International ophthalmology. 2010;30 (1); 7-13.

15. Choo MM, Martin FJ, Theam LC, et al. Alteration of tear function test in 50 patients with unilateral pterygium. International Journal of ophthalmology. 2009; 9(aa); 2060-2062.

16. Balogun MM, Ashaye AO, Ajayi BG, et al. Tear backup time in eyes with pterygia and pingueculae in Ibadan. West African Journal of Medicine 2005; 24(2): 162-166.

17. Kadayifeilar SC, Orhan M, Irkec M. Tear functions in patients with pterygium. Acta Ophthalmol Scand 1999; 76: 176-179.

18. Biedner $B$, Biger $Y$, Rothkoff $L$, et al. pterygium and basic tear secretion. Ann ophthalmol 1979;11: 12351236.

19. Pandey DJ, Mishra VK, Singh YP, et al. Quantitative and qualitative estimation of tear in pterygium. Indian $\mathrm{J}$ ophthalmol 1984;32 : 373-377.

20. Golderg L, David R. Pterygium and its relationship to the dry eye in the Bantu. Br. J Ophtalmol 1976;60 : 720721.

21. Oguzetal $H$. Tear functions in patients with pinguecula. Acta Ophthalmologica Scandinvica 2001; 262-265.

22. Kanski JJ. Clinical ophthalmology a systemic approach. Dry eye disorder. $6^{\text {th }}$ ed. Butterworth Heinemann; 2008. p. 205.

23. Roland M. Tear mucus ferring test in normal and Keratoconjunctivitissicca eyes. Chibertlnt $\mathrm{J}$ ophthalmol 1984;2:32-41.

24. Lemp MA, Hhamil JR. Factors affecting tear film break-up in normal eyes. Arch Ophthalmol 1973; 89: 103-5.

25. Forsius $\mathrm{H}$, Maertens $\mathrm{K}$, Feliman J. Changes of the eye caused by climate in Rawanda. Africa of Ophthalmic Epidemiology 1995;2:107-111.

26. Tesng SCC. Evaluation of the ocular surface in dryeye conditions. Intophthalmol Clin 1994; 34: 57-69. 